\title{
ROLE OF GOVERNANCE ON PRIMARY SCHOOL EDUCATION: EVIDENCE FROM SUB-SAHARAN AFRICAN (SSA) COUNTRIES
}

\author{
İLKÖĞRETIMM EĞITIMİNDE YÖNETIŞIMIN ROLÜ: SAHRA ALTI \\ AFRİKA (SAA) ÜLKELERINDEN KANITLAR
}

\author{
Debabrata MUKHOPADHYAY* \\ Dipankar DAS**(1)
}

\begin{abstract}
This study explores the role of governance indicators on primary school completion rate in thirty-four sub-Saharan African (SSA) countries in the year 2011 following a multiple regression model along with control variables such as per capita GNP, the share of government expenditure in education, the prevalence of HIV among the population of reproductive age. The cross-country regression results clearly demonstrate that the governance indicator namely government effectiveness has a positive impact on the primary completion rate in SSA. The linear regression analysis has also shown that HIV/AIDS prevalence to be inversely associated with the primary completion rate in SSA countries. Socioeconomic affluence and high quality of good governance are positively associated with primary completion rate. This shows a substantial part of this variation in primary school completion can be explained by differences in the quality of governance, prevalence of HIV and socioeconomic affluence in SSA countries.
\end{abstract}

Keywords: Primary School Completion Rate, Good Governance, Multiple Regression JEL Classifications: I2, I21, I22, 128, O29

Öz

Bu çalışma, 2011 yılında otuz dört Sahra Altı Afrika (SAA) ülkesinde, kişi başına düşen GSMH, eğitimde devlet harcamalarının payı, üreme çağındaki popülasyonda HIV yaygınlığı gibi kontrol değişkenleri ile birlikte çoklu regresyon modelini takiben, otuz dört Sahra Altı Afrika (SAA) ülkesinde yönetişim göstergelerinin ilkokulutamamlama oranı üzerindeki rolünü araştırmaktadır. Ülkeler arası regresyon sonuçları, yönetişim göstergesinin, yani hükümet etkinliğinin, SAA'da ilkokulutamamlamaoranı üzerinde olumlu bir etkiye sahip olduğunu açıkça göstermektedir. Doğrusal regresyon analizi ayrıca,

* West Bengal State University, Department of Economics, Kolkata, India. E-mail: debuecon@wbsu.ac.in, Orcid: 0000-0002-3159-8928

** West Bengal State University, Department of Economics, Kolkata, India. E-mail: ddas233@gmail.com, Orcid: 0000-0001-6873-2396 
SAA ülkelerindeki HIV/AIDS yaygınlığının ilkokulutamamlamaoranı ile ters orantılı olduğunu göstermiştir. Sosyoekonomik refah ve yüksek kaliteli iyi yönetişim, ilkokulutamamlamaoranı ile olumlu bir şekilde ilişkilidir. Bu, ilkokulutamamlamadaki varyasyonun önemli bir kısmının, SSA ülkelerindeki yönetişim kalitesi,HIV yaygınlığı ve sosyoekonomik refahtaki farklılıklarla açıklanabileceğini göstermektedir.

Anahtar Kelimeler: İlkokulu Tamamlama Oranı, İyi Yönetişim, Çoklu Regresyon

JEL Sinıflamas1: I2, I21, I22, 128, O29

\section{Introduction}

The cognitive skill development of an individual is found to be related to the individual income as well as aggregate economic expansion in any country from several cross-country evidence (Hanushek and Woessmann, 2015). However, additional schooling is also related to more possibility of earning, more social association, better health opportunities, and lowest birth rate, etc. (Barouni and Broecke, 2014; Peet et al., 2015; Riddell,2007). Again, from a philosophical perspective, education has been determined to lead to enhancing the human morality and dignity of the people (Nasongo et al., 2017).

According to Antoninis (2017), quality of education is a major problem in SSA countries compared to other regions globally. The "2018 World Bank Report Facing Forward: Schooling for Learning" in Arica argues that despite enormous natural resources, growing infrastructure investment, and better business environment but there is a reduced rate in social and economic transformation comparatively other countries in the world due to the fall back of stock, formation, quality, and gathering rate of its knowledge capital. Further, the report also demonstrated that there requires more capacity building of basic education and as consequences possibilities to the creation of more opportunities in African countries.

Completion of basic education with enough ability in literacy, numeracy, and science give a hard base for the country's skill for capital (Fredriksen and Kagia, 2013). The basic goal of Sustainable education is the universalization of basic education which is the working framework for 2030 of the United Nations (UN) in 2015. The main agenda of Sustainable development goals four is to"ensure inclusive and equitable quality education and promote lifelong learning opportunities for all" (UN, 2015). During the last twenty-five years, the Sub-Saharan African (SSA) countries have focused on enrolling students at the primary level which is the first step in building human capital, in which many countries in the region have achieved initial success. Apart from this enrolment rate, there are other indicators of assessing the state of basic education attainment such as attendance rate, drop out and learning achievement, etc. While considering primary education in Sub-Saharan Africa, (Daun,2000), an original work had demonstrated that educational indicators like literacy rate and enrolment rate are both economic matter as well as the moral issues in the SSA countries. We consider the primary school completion rate as the indicator for assessing the state of basic education in Sub-Saharan countries and evaluate the role of governance for this educational indicator across the countries. 
At the individual micro(household) level, there are many determinants of primary school completion rate such as distance from school, sanitation facilities in the school premises, household income, teaching and learning infrastructure, pupil-teacher ratio, etc. However, at the macro level, country-level differences in infrastructure, governance matters visibly exist in the SSA regions in achieving these goals. Compared to Botswana, Cabo Verde Comoros, Equatorial Guinea countries like Rwanda, South Africa, Sudan, Uganda, and Zimbabwe have been facing many socio-economic challenges to education in the recent past particularly since the mid-1990s.

Country-level governance is a vital macro-level determining factor to enhancing the standard of primary education apart from conventional macroeconomic fundamentals such as per capita Gross National Product (GNP), the share of expenditure in primary education of national income, etc. however good governance implies the standard of civil services. It also includes the potentiality of the government to improving the policies not only that its ability to executionof such policies and how such policies are in favor of the public in the countries. Moreover, good governance also secures primary education in the country and allows to implementation of suitable policies in the education sector such implies the regulatory quality of the country.

Good governance in a country leads to an increase in school retention and reduces regional disparities. Moreover, poor governance badly affects the educational performances at the basic level. According to the World Bank, there are six governance indicators at the country level namely, voice and accountability, government effectiveness, regulatory quality, rule of law, control of corruption, and political stability. However, the SSA countries face several institutional challenges like fund shortage, poor infrastructure, the problem in the implementation of policies in educational development, poor teacher-pupil ratio, lack of quality teachers, etc. Good governance has a vital role to play to overcome this shortcoming in the education system in SSA countries.

According to Ackerman (2005), the governance indicator like accountability is "a pro-active process by which public officials inform about and justify their plans of action, their behavior, and results, and are sanctioned accordingly. "Accountability is an essential responsibility of government servants to proper implementation of policies which already pre-decided. Even though real accountability is a necessary condition for effective education service but it is seldom in the education system in the world. Furthermore, good governance in any country is also an essential productive stimulus in all levels of the education sector. Not only that standard and informative performance to make and assist desirable behavior in the education sector.

It is necessary to mention that among all governance indicators corruption is the most crucial factor in each country. In recent times many studies demonstrate that corruption in the education sector like distribution and allocation of expenses in the education system are reduced by the newly allocated fund. Many research studies are revealed that the government budget on education is negatively related to the corruption in the education sector in the countries (Mauro, 1998; Delavallade, 2006; De la Croix and Delavallade, 2007, 2009). 
Moreover, during the long period, SSA countries are facing several social and economic challenges in the education sector. At that time this region was mainly involved to gather human capital for creating more job opportunities as well as investment in the education sector in the world (Majgaard and Mingat, 2012). Although, most of the countries of SSA countries have not reached the basic goal of primary education not only that these countries could not attain universal basic education. But during the last twenty years, this basic education level a little bit increased across the SSA regions. According to UNESCO report more than $1 / 5$ of the pupil aged $6-11$ years are outside of the school in the SSA countries which is followed by $1 / 3 \mathrm{rd}$ of children ages 12 14 years. Globally, Africa is home to more than half of out of school children of primary age (611 years) (UNESCO, 2016). As per the UNESCO report, 38 million children are out of school in SSA countries which is the highest of all regions. The report also demonstrated that there are out sided school children in Ethiopia and Nigeria was about more than five million besides it was more than one million in Burkina Faso, Mali, and Niger. Not only that more than 2/3 rd of the SSA regions are outside school children have not entre in the school. The report revealed that more than $80 \%$ out sided students live in rural areas and they are coming from the poorest income group. An important observation from this report is that a child whose mother has no basic education and it is likely to be twice as out of school.

Moreover, the Human Immunodeficiency Virus (HIV) is crucially regarded as a disease of poverty and ignorance in many third world countries. However, within the SSA countries, vary in concerning the popularity of these germs. Among developing countries, lower per capita income is related to higher HIV prevalence in urban areas (World Bank, 1996). According to UNAIDS (1998), a lower adult literacy rate of the people results in a higher HIV epidemic in the countries. However, at least two concerning warnings like there is a huge gap between income and education levels among the males and females have also created large HIV epidemics (World Bank, 1997). On the other, due to the modernization of the countries or enormous migration, urbanization may rush the rapid and extensive HIV infection (Caldwell and Caldwell, 1993). This situation was hugely demonstrated in SSA countries and sometimes it (HIV epidemics) compares with the epidemics of development than of poverty. Notably, some countries had achieved the highest level of adult literacy rate but these countries were suffering from huge HIV epidemics (UNAIDS, 1998).

This paper investigates the role of governance indicators on educational outcomes, especially the primary completion rate in thirty-four (among forty - nine) SSA countries. This study has also used other relevant control variables such as per capita GNP, the share of government expenditure in the education sector, prevalence of HIV while focusing on the impact of governance indicators on primary education. Depending upon data availability this study considers thirty-four countries using a multiple cross-section regression in the year 2011. Thus, good governance in education systems promotes the effective or prominent delivery of education services in the country. Government expenditure in education is another factor for the improvement of education in the country. Such a relevant study has revealed that there is a positive relationship between educational expenditure and the development of educational institutions in developing and 
transition countries (Gupta et al.,2002). Moreover, educational outcomes and health outcomes both are consistent in the countries. Educational outcomes concerning the school enrolment and dropout rate are dependent on educational spending in the countries.

\section{Literature Review}

There exists limited literature involving the role of governance indicators on educational outcomes in the context of developing countries. One such notable study was carried out by Kaufman et. al. (1999) whose objective was to explore the relationship between governance indicators and educational outcomes. In this study, they observed that improvement of one such indicator like control of corruption leads to higher adult literacy rates in cross-section studies.

Gupta et al. (2002) considered 50 transition and development countries, and found that health outcomes and educational feedback are correlated based on all educational spending and allocational public funds. Educational feedback means both primary and secondary education enrollment ratio and school dropout ratio. Besides health feedback refers to infant and child mortality rates in the countries. Although, the research study has considered the 2SLS (Two-Stage Least Square) method to the estimation of causality in the education models besides the health models represent only weak proof of that causality in the country.

Rajkumar and Swaroop (2008) investigated empirically that their most vital factor is quality of governance for government expenditure on health and education in the country. The empirical results shown as rising health care spending is equal to $1 \%$ of GDP accelerated to a decrease of 0.32 $\%$ in mortality with good governance. Besides a $0.2 \%$ decrease in countries with good governance and there is no remarkable decrease in the countries with weak governance. Furthermore, rising education expenditure on public education equivalent to $1 \%$ of its GDP may generate a $0.7 \%$ decrease in elementary education dropout in the countries with good governance.

Samarraiand Samer (2009), have argued that in their study the role of government in the recovery of inequality in Bangladesh. They suggested that the central role of the government is to improve the education sector in the country. Effective accountability and suitable government policies are the basic pillars to reduce the inequities in the education sector.

Henard and Mitterle (2010) had explained the role of governance indicators on the quality of education as well as in the sustainability of education in African countries. Governance plays a pivotal role in learning in primary education as well as higher education and progress in education in Africa.

According to Gaygizis (2013), his research study revealed that there is a strong impact of the institution on economic development and social development. In that regard, the study considered the importance of governance indicators on social and economic development. 
Dao (2015) has described in the study that requires huge reforms in the educational policy and governance in Vietnam. The study concludes that there are slow performances in the national institutions and poor performance in the quality of education.

Yirdaw (2016) explained in the study that educational leadership and governance factors are a major contribution to the quality of educational institutions in Ethiopia. In this regards the study used a qualitative case study methodology. The empirical results revealed that educational leaders focusing on good governance improves quality of education.

Abugre (2018) has demonstrated that governance indicators are highly relevant in the quality of primary education. One of the main factors considered in the study is the teacher pupil ratio that is used for the measures of quality of primary education.

\section{Objective of The Study}

This study is aimed to study the impact of governance indicators on the primary completion rate in forty-nine SSA countries in the year2011. In the final model, the study has selected thirty-four SSA countries among all forty-nine countries for the year 2011 due to the unavailability of data for the remaining fifteen countries. Our research study mainly focuses on the impact of six governance indicators and some conventional variables like per capita income of the counties, HIV prevalence among the population of reproductive age, the share of government expenditure in the education sector, etc. on primary completion rate in thirtyfour SSA economies.

\section{Data and Methodology}

There are forty-nine SSA countries. However, this study considers only thirty-four Sub-Saharan African countries ${ }^{1}$ for the year 2011 in the final model because of the unavailability of data for all required explanatory variables for this year. As already stated, in our study we have considered primary schooling completion rate in education as the dependent variable which is an important outcome variable in primary education apart from attendance rate, enrollment rate, drop out etc. The data has been taken from different sources such as the World Development Report of the World Bank (2011) and various fact sheets of the UNESCO.

Considering $\mu_{t}$ as the mean of the concerned education outcome indicator (primary education completion rate/school enrollment rate) of all the SSA countries at time $t$ and $\sigma_{t}$ is the standard deviation of these values at time $t$. Then, $C V_{t}$ defined as $C V_{t}=\frac{\sigma_{t}}{\mu_{t}}$, is the coefficient of variation of

1 Thirty-four selected SSA countries are Benin Republic, Burkina Faso, Burundi, Cameroon, Central Africa Republic, Chad, Côte d'Ivoire, Congo Brazzaville Congo Democratic Republic, Eritrea, Ethiopia, Gabon, Gambia, Ghana, Guinea, Kenya, Liberia, Malawi, Mali, Mauritania, Mozambique, Niger, Rwanda, Senegal, Sierra Leone, Sudan, Tanzania, Uganda, Togo, Zimbabwe, Cabo Varde, Eswatini, Madagascar, South Sudan. 
these values at time $t$. Now, we compare such measures of disparities in educational achievements across the SSA countries like $C V_{t^{\prime}}$ and $\sigma_{t}$ at different time points for the concerned outcome variable. Declining values of these measures indicate lowering of regional disparities in these outcome indicators which should be desirable from socio - economic perspectives.

\section{I. A Brief Description of the Study Variables}

Primary completion rate (Outcome/dependent variable) - The primary completion rate expresses as a percentage of the relevant age group. The primary completion rate, or gross intake ratio in the last grade of primary education, is the number of new entrants (enrolments minus repeaters) in the last grade of primary education, regardless of age, divided by the population at the entrance age for the last grade of primary education in SSA countries.

Government expenditure on education - This explanatory variable has been defined as a total percentage of gross domestic products (GDP) in the country i.e., General government expenditure on education (current, capital, and transfers) is expressed as a

percentage of GDP. It includes expenditure funded by transfers from international sources to the government. General government usually refers to the local, regional and central governments.

Prevalence of HIV-This independent variable measures the prevalence of HIV infection among the population of the reproductive age group i.e., it refers to the percentage of people ages 15-49 that are infected with HIV.

\subsection{A Brief Dimension of Six Governance Indicators (Other Independent Variables)}

I. Voice of accountability (VA) - Measured by citizens or people capable of selecting their government freely and fully the privileged expression to their speech in the countries. They have the freedom to construct the association and the press.

II. Political stability (PA) - It is the perception of the probability of unstable government or displaced government by the various brutal or unconstitutional motivations and anarchism.

III. Government effectiveness (GE) - It is measured by the many aspects of the attribute of activities of the government, the skill of the government services works free from the political decision. Not only that, the dignity of policy sketch and execution in the country, and the reliability of the government's loyalty to such policies implementation.

Regulatory quality (RQ) - It is measured the efficiency of the government to sketch and implement the required policies and maintain that the act about the permission of private sector development in the economy. 
Rule of law (RL) - Measured by which institution have faith in and bound by the acts of the country, and in specific the dignity of agreement enactment, property rights, the police, and the courts, as well as the probability of offense and brutality.

Control of Corruption (CC) - Measured by that government power is avail for personal profit, including both small-minded and supreme shape of corruption, as well as to measure of the state by cream and personal regards in the economy.

Each governance indicator takes the values -2.5 to 2.5. The value of any governance indicator is -2.5 means its worst position of the economy among all other emerging countries. Conversely, its highest value is 2.5 indicates that the strong position of a particular indicator in the country with respect to other countries. There are six governance indicators taken into account only in the year 2011. All the governance indicators used here are taken from the World Bank.

Governance in education means the power of decision making and commanding power in the education system. According to the Network of Experts in Social Sciences of Education and Training (NESSE, 2018) "Education governance is concerned with how the funding, provision, ownership, and regulation of education and training systems are coordinated, and at what level; local, regional, national and supranational."

\subsection{Methodology}

The simple econometric followed in this analysis model is in the following form:

$$
y_{i}=\alpha+\beta_{1} X_{1 i}+\beta_{2} X_{2 i}+\beta_{3} X_{3 i}+\sum_{j=1}^{6} \delta_{j} Z_{j}+\varepsilon_{i}
$$

Where,

$y_{\mathrm{i}:}$ Primary education completion rate in the ith SSA country in the given year 2011.

$\alpha$ : Intercept term.

$\beta$ 's: Coefficients of the independent variables.

$\mathrm{X}_{1 \mathrm{i}}$ : Prevalence of HIV in the given year in the ith SSA country.

$\mathrm{X}_{2 \mathrm{i}}$ : Govt expenditure on education in the given year in the ith SSA country.

$\mathrm{X}_{3 \mathrm{i}}$ : Per capita income in the given year in the ith SSA country.

$\mathrm{Z}_{\mathrm{ji}}$ 's: $\mathrm{jth}_{\text {governance indicator of ofi }}{ }^{\text {th }}$ countries in a given year among the six already stated.

$\delta_{\mathrm{j}}, \mathrm{s}$ : Coefficients corresponding to the six governance indicators.

$\varepsilon$ : The disturbance or error term. It takes into account both the unobservable unit of observation specific effects and the remainder of the disturbance. 


\section{Empirical Results}

This section presents empirical results following the methodology discussed in the previous section. As already stated, that the main objective of this empirical exercise is to evaluate the role of governance indicators along with someimportant macroeconomic variables on explaining the variation of primary education completion rate in SSA countries in the year 2011 following an exploratory econometric exercise. We have reported the latest primary education profile of 49 SSA countries in Table 1 presented below. We have presented here two most important basic education indicators for the SSA countries namely primary completion rate and school enrolment at the primary level. The table shows that most of the SSA countries have achieved remarkable progress in enrolment rate in many cases more than $90 \%$.

However, countries like Niger and Sudan have below 70\% even in the year 2011. The primary completion rate, however, is still below 50\% in many SSA countries like Angola, Chad, Niger South Sudan etc. along with performing states like Botswana, Ghana, Mauritius. Thus, there are wide variances among the SSA countries in terms of these educational outcomes.

Table I: State of Basic Education in 49 SSA Countries during Last Thirty Years

\begin{tabular}{|l|c|c|c|c|c|c|}
\hline SSA Countries & $\begin{array}{c}\text { Primary } \\
\text { completion } \\
\text { rate1991 }\end{array}$ & $\begin{array}{c}\text { Primary } \\
\text { completion } \\
\text { rate 2001 }\end{array}$ & $\begin{array}{c}\text { Primary } \\
\text { completion } \\
\text { rate 2011 }\end{array}$ & $\begin{array}{c}\text { Enrollment } \\
1991\end{array}$ & $\begin{array}{c}\text { Enrollment } \\
2001\end{array}$ & $\begin{array}{c}\text { Enrollment } \\
2011\end{array}$ \\
\hline Angola & 28.56 & NA & 46.09 & 65.54 & NA & 118.65 \\
\hline Benin Republic & 21.39 & 41.68 & 71.69 & 58.22 & 90.74 & 122.73 \\
\hline Botswana & 88.78 & 96.36 & NA & 105.33 & 109.33 & NA \\
\hline Burkina Faso & 19.95 & 26.68 & NA & 33.72 & 46.44 & 81.59 \\
\hline Burundi & 46.42 & 25.35 & 56.97 & 71.70 & 62.02 & 143.91 \\
\hline Cabo Verde & NA & 98.06 & 91.53 & 124.50 & 119.24 & 100.96 \\
\hline Cameroon & 55.71 & NA & 72.64 & 97.38 & 102.98 & 110.09 \\
\hline $\begin{array}{l}\text { Central Africa } \\
\text { Republic }\end{array}$ & 27.91 & NA & 41.58 & 64.84 & 77.20 & 89.81 \\
\hline Chad & 18.17 & 24.44 & 34.08 & 51.22 & 66.18 & 89.32 \\
\hline Côte d'Ivoire & 45.21 & 49.28 & NA & 68.18 & 75.40 & 80.64 \\
\hline Congo Brazzaville & 54.36 & 56.24 & 73.70 & 121.30 & 100.74 & 106.89 \\
\hline $\begin{array}{l}\text { Congo Democratic } \\
\text { Republic }\end{array}$ & 52.33 & NA & 65.61 & 79.62 & NA & 101.23 \\
\hline Djibouti & 24.50 & 26.42 & 47.00 & 32.83 & 36.47 & 61.34 \\
\hline Equatorial Guinea & NA & NA & 42.17 & NA & 106.27 & 67.56 \\
\hline Eritrea & NA & 36.75 & 45.07 & 21.53 & 59.52 & 55.53 \\
\hline Eswatini & 60.65 & 59.10 & 75.44 & 94.16 & 95.73 & 112.09 \\
\hline Ethiopia & NA & 27.60 & 52.61 & 31.46 & 60.26 & 94.50 \\
\hline Gabon & NA & NA & NA & NA & 136.72 & 138.72 \\
\hline Gambia & NA & 73.84 & 68.33 & 58.41 & 91.73 & 80.88 \\
\hline Ghana & 65.61 & 68.02 & 89.00 & 79.95 & 80.93 & 104.28 \\
\hline Guinea & 17.60 & 33.12 & NA & 37.13 & 60.61 & 89.00 \\
\hline
\end{tabular}




\begin{tabular}{|l|c|c|c|c|c|c|}
\hline Guinea-Bissau & NA & NA & NA & NA & 87.17 & NA \\
\hline Kenya & NA & NA & NA & 98.37 & 96.12 & NA \\
\hline Lesotho & 60.01 & 65.15 & 72.82 & 110.74 & 117.62 & 110.63 \\
\hline Liberia & NA & NA & 65.36 & NA & NA & 102.64 \\
\hline Madagascar & 33.79 & 36.20 & 70.70 & 94.55 & 102.53 & 143.41 \\
\hline Malawi & 32.85 & 62.44 & 68.08 & 76.23 & 137.73 & 135.16 \\
\hline Mali & NA & 35.07 & 58.18 & 27.90 & 62.40 & 84.08 \\
\hline Mauritius & 114.14 & 101.89 & 98.43 & 110.80 & 102.37 & 102.99 \\
\hline Mauritania & 32.39 & 44.76 & NA & 48.85 & 81.35 & 94.80 \\
\hline Mozambique & 27.45 & 19.07 & 53.42 & 61.90 & 79.94 & 106.15 \\
\hline Namibia & NA & 93.63 & 77.93 & 125.83 & 113.34 & NA \\
\hline Niger & 17.32 & 19.36 & 44.22 & 27.12 & 35.33 & 66.49 \\
\hline Nigeria & NA & NA & NA & 85.59 & 96.33 & 90.62 \\
\hline Rwanda & 43.55 & 24.67 & NA & 75.09 & 109.31 & 144.36 \\
\hline $\begin{array}{l}\text { Sao Tome and } \\
\text { Principe }\end{array}$ & & & & & & \\
\hline Senegal & NA & NA & 107.23 & 147.84 & & 117.77 \\
\hline Seychelles & 101.60 & 105.65 & 112.84 & 99.74 & 104.99 & 113.00 \\
\hline Sierra Leone & NA & NA & 66.38 & 42.92 & 73.88 & 110.73 \\
\hline Somalia & NA & NA & NA & NA & NA & NA \\
\hline South Africa & 73.45 & NA & NA & 105.35 & 103.53 & 94.55 \\
\hline South Sudan & NA & NA & 25.73 & NA & NA & 84.76 \\
\hline Sudan & NA & NA & NA & NA & 59.77 & 69.75 \\
\hline Swaziland & NA & NA & NA & NA & NA & NA \\
\hline Tanzania & 62.61 & 54.95 & NA & 70.00 & 73.33 & 92.02 \\
\hline Togo & 36.38 & 72.17 & 72.04 & 98.04 & 115.78 & 124.33 \\
\hline Uganda & NA & 59.82 & 52.85 & 70.71 & 131.75 & 109.09 \\
\hline Zambia & NA & NA & 93.56 & 78.35 & 96.66 \\
\hline Zimbabwe & 92.6124 & NA & 104.63 & 105.66 & NA \\
\hline Nource: & & & & & \\
\hline
\end{tabular}

Source: The World Bank

Note: 'NA' indicates data not available. All figures are given in percentages.

We now report, in Table 2, the country-level disparity results for education outcome indicators across SSA countries. The values of inequality measures such as S. D. and C.V. are presented for the years 1981, 1991, 2001 and 2011. The S.D. values for these years for primary education complete rates are 26.357, 25.803,27.022 and 21.691 implying that although the value is lower in 2011 in comparison with 2011, no declining trend is present over four the decades. The same observation holds for C.V. as well. However, for school enrollment rate, these values both standard deviation and Coefficient of variation show smooth declining trend over the decades. This exploratory econometric analysis demonstrates that although inter-country inequality has declined across the Sub-Saharan countries over the decades in terms of school enrollment rate, the same is not for education completion rate. 
Table 2: Results on Regional Disparity in Educational Outcomes Across the SSA Countries

\begin{tabular}{|l|c|c|c|c|}
\hline Educational Outcomes & \multicolumn{2}{|c|}{ Primary Completion Rate } & \multicolumn{2}{c|}{ School Enrolment Rate at Primary level } \\
\hline Year & $\begin{array}{c}\text { Standard } \\
\text { Deviation (S D) }\end{array}$ & $\begin{array}{c}\text { Coefficient of } \\
\text { Variation (C V) }\end{array}$ & $\begin{array}{c}\text { Standard } \\
\text { Deviation (S D) }\end{array}$ & $\begin{array}{c}\text { Coefficient of } \\
\text { Variation (CV) }\end{array}$ \\
\hline 1981 & 26.357 & 0.549 & 36.802 & 0.446 \\
\hline 1991 & 25.803 & 0.552 & 30.597 & 0.405 \\
\hline 2001 & 27.022 & 0.501 & 24.472 & 0.272 \\
\hline 2011 & 21.691 & 0.337 & 22.169 & 0.219 \\
\hline
\end{tabular}

Source: Authors' own calculation

We have presented the brief summary statistics of governance indicators in Table 3 below. The mean and median values of all the six governance indicators viz., voice and accountability, government effectiveness, regulatory quality, rule of law, control of corruption, and Political Stability are negative among the thirty-four SSA countries in the year 2011. The values of standard deviation are high in all the factors of governance indicators. For the normality of data Jarque - Bera (1987) test has been considered in the study. Itis based on the OLS residuals, skewness, and kurtosis. The value of Jarque - Berastatisticof the governance indicator accountability is 0.584 and probability of such indicator shows $75 \%$ under normality assumption. Therefore, the study does not reject the variable like normally distributed. Similarly, the values of Jarque - Bera statistics of other components of the governance are shown in Table 3.

Table 3: The Basic Statistics of Six Governance Indicators in the SSA Countries

\begin{tabular}{|l|c|c|c|c|c|c|c|}
\hline \multicolumn{7}{|c|}{ Summary statistics of all governance indicators for the year, 2011 } \\
\hline & Mean & Median & Std. Dev. & Skewness & Kurtosis & $\begin{array}{c}\text { Jarque - } \\
\text { Bera }\end{array}$ & Probability \\
\hline Voice and Accountability & -0.7373 & -0.930 & 0.665898 & 0.320826 & 3.019309 & 0.583796 & 0.746845 \\
\hline Political Stability & -0.7164 & -0.670 & 0.774522 & -0.3437 & 2.560577 & 0.943216 & 0.623998 \\
\hline Government Effectiveness & -0.869118 & -0.84000 & 0.477070 & 0.138686 & 2.612547 & 0.321307 & 0.851587 \\
\hline Regulatory Quality & -0.7600 & -0.700 & 0.561408 & -0.6640 & 3.002331 & 2.498564 & 0.286711 \\
\hline Rule of Law & -0.8097 & -0.860 & 0.4937 & 0.2048 & 2.8237 & 0.2820 & 0.8684 \\
\hline Control of Corruption & -0.7070 & -0.660 & 0.502729 & 0.946678 & 4.662293 & 8.993022 & 0.011148 \\
\hline
\end{tabular}

Source: Authors' own computation.

Figures 1 to 6 representing the distribution of the governance indicators of thirty - four SSA countries in the year 2011 are shown below. The distribution of all the variables does not follow the normal distribution. The distribution of the component voice and accountability lies between the value -2.18 and 0.98 . The highest value of political stability is 0.72 and the lowest value of that factor is -2.53 . The factors government effectiveness, regulatory quality, rule of law, and control of corruption lies between $-1.83-0.16,0.16-2.24,0.47-1.78,-1.63-$ 0.86 respectively. 
Figure I: Distribution of Voice and Accountability Component.

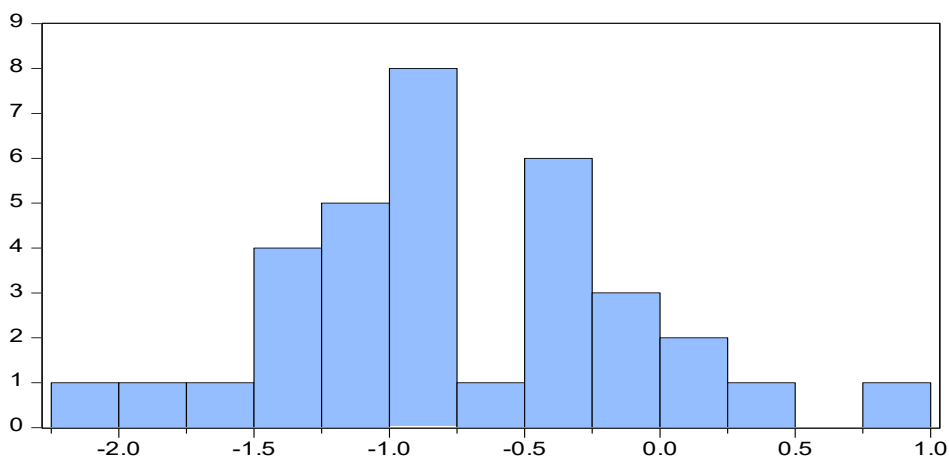

Source: World Bank (2011)

Figure 2: Distribution of Political Stability Component

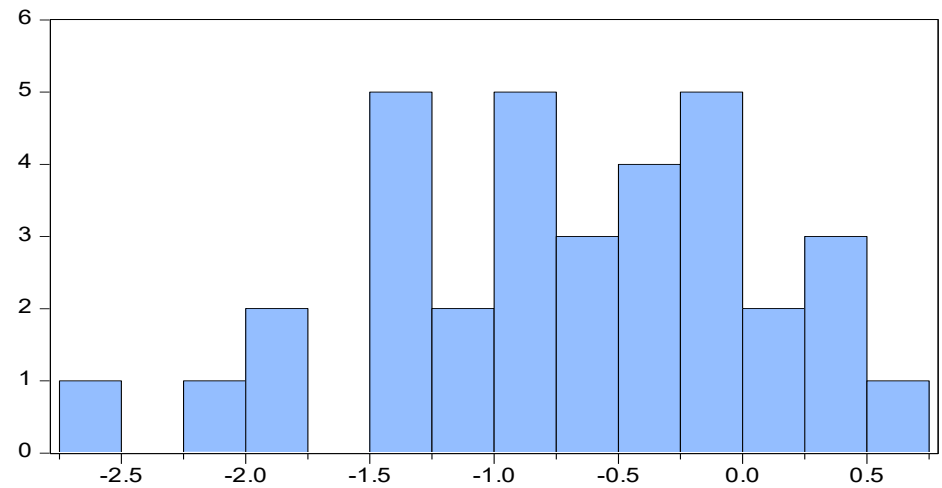

Source: World Bank (2011)

Figure 3: Distribution of Government Effectiveness Component

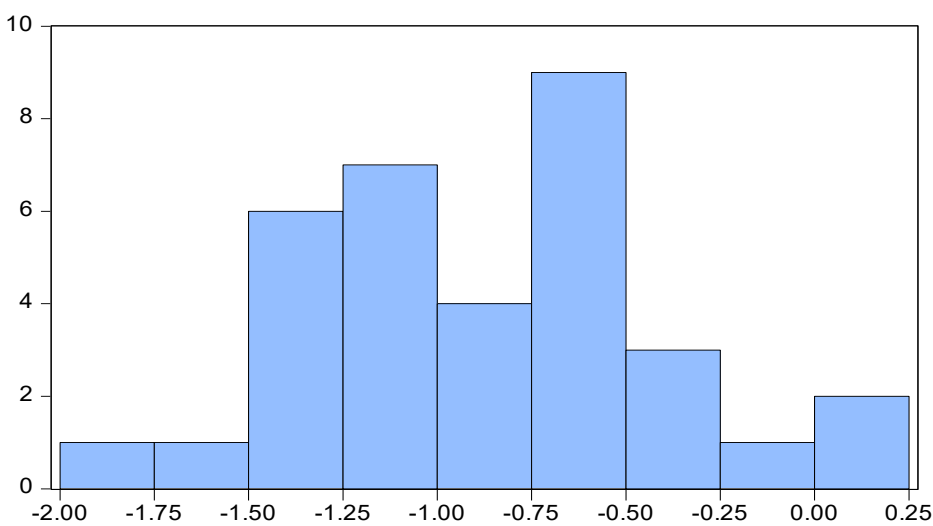

Source: World Bank (2011) 
Figure 4: Distribution of Regulatory Quality Component

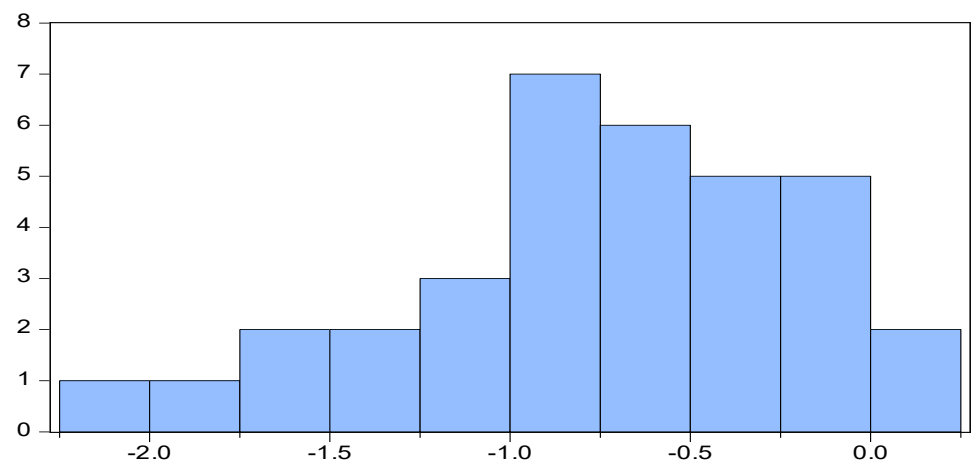

Source: World Bank (2011)

Figure 5: Distribution of Rule of Law Component

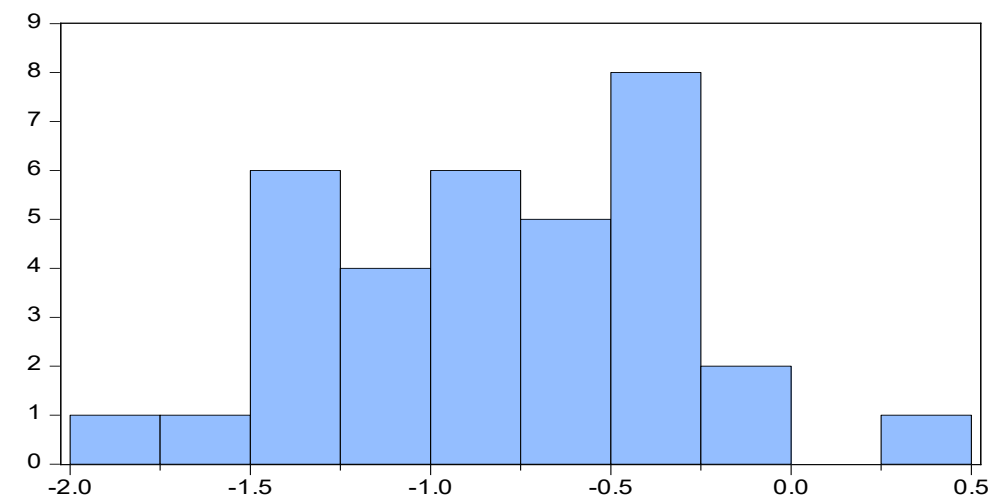

Source: World Bank (2011)

Figure 6: Distribution of Control of Corruption Component

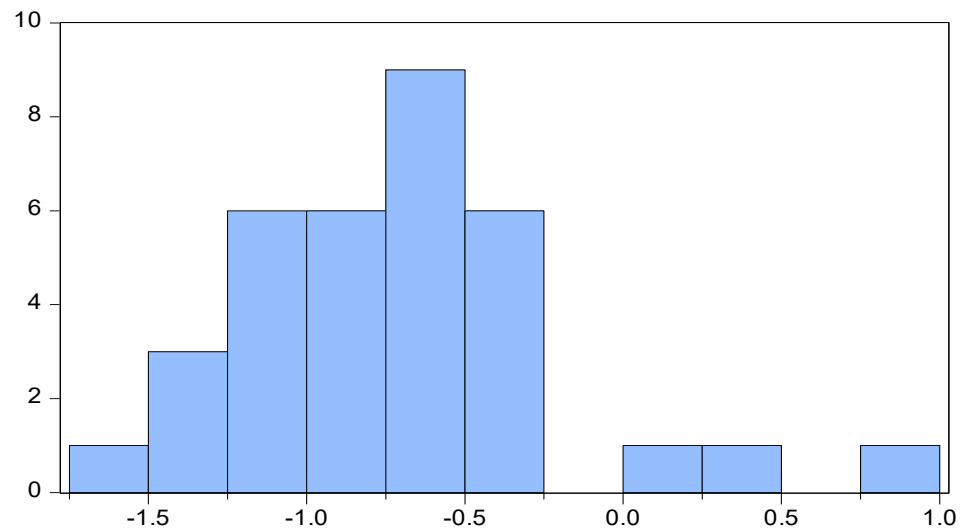

Source: World Bank (2011) 
In Table 4 given below, the research study has presented the results on regression analysis. These results of the multiple regression analysis by using the ordinary least square (OLS) method found two control variables and two governance indicators as statistically significant.

Table 4: Cross Section Regression Results for SSA Countries in the Year of 2011

\begin{tabular}{|l|c|c|c|c|}
\hline Variables & Co-eff & S.E. & t-Statistic & probability \\
\hline Constant & 84.34877 & 8.058841 & 10.46661 & $0.0000^{*}$ \\
\hline HIV prevalence & -2.352716 & 0.819521 & -2.870842 & $0.0077^{\star}$ \\
\hline Per capita income & 0.004958 & 0.001576 & 3.146203 & $0.0039^{*}$ \\
\hline Government effectiveness & 66.51933 & 17.97978 & 3.699673 & $0.0009^{*}$ \\
\hline Rule of law & -50.49990 & 18.08004 & -2.793131 & $0.0093^{*}$ \\
\hline Total no. of observations & 34 & & & \\
\hline Log-likelihood values & -148.6922 & & & \\
\hline Durbin-Watson Statistics & 1.586309 & & & \\
\hline F test & 3.765159 & & & \\
\hline Adjusted R & 0.295260 & & & \\
\hline $\mathbf{R}^{2}$ & 0.402039 & & & \\
\hline
\end{tabular}

* Statistically significant at $1 \%$ level.

** Statistically significant at $5 \%$ level.

Source: Authors own computation.

The overall fit of the regression is represented by the value of $\mathrm{R}^{2}$ which is an important measure of goodness of fit of the regression with the value being 0.402 . It indicates that over $40 \%$ variation in primary school completion rate can be explained by these variables. The results show that the governance indicators like government effectiveness are positively associated with primary school completion rate in SSA countries. We have also found, that prevalence of HIV among the population of reproductive age is inversely correlated with the primary completion rate in SSA countries in 2011. It is statistically significant at $1 \%$ level. Per capita income representing economic well-being has also favorable impact on primary completion rate in SSA countries in the year 2011. It is also statistically significant at $1 \%$ level. Rising per capita income leads to higher primary completion rate in the SSA countries. In addition, as already stated two governance indicators are statistically significant at $1 \%$ level namely, government effectiveness is positively the primary completion rate. However, the rule of law in SSA countries has a negative effect.

\section{Conclusion}

This study has examined the influence of governance indicators and some other macroeconomic variables on the primary education completion rate in SSA countries in the year 2011 by using an exploratory econometric exercise. Associations between country-level characteristics and primary education complete rate were examined using linear regression analysis has shown that prevalence of HIV/AIDS among the population of reproductive age is inversely associated with primary completion rate in SSA.The empirical results based on 34 SSA countries show that 
socio-economic affluence and high quality of good governance are positively associated with primary completion rates. We also find that a substantial part of this variation in primary school completion can be explained by differences in the quality of governance, prevalence of HIV and socio-economic affluence in the SSA countries. The United Nations has targeted seventeen Sustainable Development Goals (SDG) to achieve by 2030 where obtaining quality education at the primary level is of utmost importance. Although there has been an increase in enrollment ratio at the primary level in the SSA countries at the same time there has been a low completion rate which requires special attention and in terms of policy making institutional intervention in terms of incentives for completing basic education. This study identifies the underlying causes of variation in achieving this education outcome across the SSA countries and states that good governance in terms of government effectiveness can play a significant role in this regard along with of course socio-economic development.

It may, however, be noted that six governance indicators which stand for overall country level governance has limitation to represent governance of the educational system in a specific country. Future research may consider other relevant variables to take care of governance at the educational level.

\section{References}

Abugre, J. B. (2018). Institutional governance and management systems in Sub-Saharan Africa higher education: developments and challenges in a Ghanaian Research University.Higher Education,75(2): 323-339.

Ackerman, J.(2005). Co-Governance for Accountability: Beyond "Exit" and "Voice", World Development, 32(3): 447-463.

Antoninis, M. (2017). Education in Sub-Saharan Africa gets a very poor report card, Business Day. https:// www.businesslive.co.za/bd/world/africa,10-25-education-in-sub-saharan-africa-gets-a-very-poorreportcard/ (Accessed: 25/10/2018).

Barouni, M. and Broecke, S. (2014). The Returns to Education in Africa: Some New Estimates.Journal of Development Studies, 50 (12):1593-1613. doi:10.1080 /00220.388.2014.936394.

Caldwell, J. C. and Caldwell, P. (1993). The nature and limits of the sub-Saharan African AIDS epidemic: evidence from geographic and other patterns. Population andDevelopment Review, 19(4):817-848.

Dao, K. V. (2015). Key challenges in the reform of governance, quality assurance, and finance in Vietnamese higher education - a case study. Studies in Higher Education, 40(5): 745-760.

Daun, H. (2000). Primary education in Sub-Saharan Africa - a moral issue, an economic matter, or both?Comparative Education, 36(1):37-53.

De la Croix, D. and Delavallade, C. (2007). Corruption et Allocation Optimale de l'Investement Public. Revenue Economique, 58,637-647.

De la Croix, D. and Delavallade, C. (2009). Growth, Public Investment and Corruption with Failing Institutions. Economics of Governance, 10,187-219.

Delavallade, C. (2006). Corruption and Distribution of Public Spending in Developing Countries. Journal of Economics and Finance, 30,222-239. 
Fredriksen, B. and Kagia, R. (2013). Attaining the 2050 vision for Africa: breaking the human capital barrier. Global journal of emerging market economies, sage, vol. 5, 269-328.

Gaygizis. E. (2013). How are cultural dimensions and governance quality related to socioeconomic development? The Journal of Socio-Economics, v. 47,170-179.

Gupta, S., Verhoeven, M.,and Tiongson, E. R. (2002). The effectiveness of government spending on education and health care in developing and transition economies.European Journal of Political Economy, 18(4),717-737.

Hanushek. E. and Woessmann, L. (2015). The Knowledge Capital of Nations: Education and the Economics of Growth. Cambridge, MA: MIT Press.

Henard, F. and Mitterle, A. (2010). Governance and quality guidelines in higher education: A review of governance arrangements and quality assurance guidelines. Paris, France: OECD.

Jarque, C. M. and Bera, A. K. (1987). A Test for Normality of Observations and Regression Residuals. International Statistical Review, vol. 55, 1987, 163-172.

Kaufmann, D., Kraay, A., andZoido-Lobaton, P. (1999). Governance Matters. The World Bank, Policy Research Working Paper, 2196. Washington, DC: World Bank.

Majgaard, K. and Mingat, A. (2012). Education in Sub-Saharan Africa: A Comparative Analysis. World Bank Study; Washington, DC: World Bank. https://openknowledge.worldbank.org/handle/10986/13143.

Mauro, P. (1998). Corruption and the Composition of Government Expenditure.Journal of Public Economics, 69,263-279.

Nasongo J., Mukonyi P., andNyatuka B. (2017). An Analysis of Nelson Mandela’s Philosophy of Education. In: Soudien C. (eds) Nelson Mandela. Comparative and International Education (A Diversity of Voices). SensePublishers, Rotterdam.

Network of Experts in Social Sciences of Education and Training (2018). Education Governance, available at: http://www.nesse.fr/nesse/activities/research-mapping/educational-governance.

Peet, E. D., Fink,G., and Fawzi, W. (2015). Returns to Education in Developing Countries: Evidence from the Living Standards and Measurement Study Surveys. Economics of Education Review, 49 (C):69-90

Rajkumar, Sunil, A., and Swaroop, V. (2008). Public spending and outcomes: Does governance matter?Journal of development economics, 86.1: 96-111.

Riddell, W. C. (2007). The Impact of Education on Economic and Social Outcomes: An Overview of Recent Advances in Economics. In Fulfilling Potential, Creating Success: Perspectives on Human Capital Development, edited by G. Picot, R. Saunders, andA. Sweetman,55-100. Montreal: McGill-Queen's UniversityPress.

Samarrai, A. and Samer. (2009). The impact of governance on education inequality: Evidence from Bangladesh. Public Administration and development, 29(3): 167-179.

Sustainable Development Goal 4 (SDG 4) (2021). Education within the 2030 Agenda for Sustainable Development. (2021), from https://sdg4education2030.org/the-goal.

UNAIDS. (1998). Report on the Global HIV/AIDS Epidemic. Geneva, UNAIDS.

UNESCO. (2016). Retrieved from https://unesdoc.unesco.org/ark:/ 48223/ pf000.023.2689.

World Bank (1996). Social Indicators of Development, World Bank.

World Bank (1997). Social Indicators of Development, World Bank.

Yirdaw, A. (2016). Quality of Education in Private Higher Institutions in Ethiopia: The Role of Governance. Sage Open, 1-12. DOI: 10.1177/215.824.401562495.

http://www.worldbank.org/ database/ (2011). 